\title{
Nysius cymoides (Spinola) on Chenopodium quinoa Willd. cultivated in Italy
}

\author{
S. Bocchi, ${ }^{1}$ D. Cinquanta, ${ }^{1}$ M. Negri, ${ }^{1}$ P. Dioli, ${ }^{2}$ L. Limonta ${ }^{3}$ \\ ${ }^{1}$ Department of Agricultural and Environment Sciences - Production, Landscape and Agroenergy, \\ University of Milano; ${ }^{2}$ Museo Civico di Storia Naturale, Milano; ${ }^{3}$ Department of Food, \\ Environmental and Nutritional Sciences, University of Milano, Italy
}

\begin{abstract}
Quinoa (Chenopodium quinoa Willd.) (Family: Amaranthaceae APG classification) is an Andean grain recently introduced on the European market and cultivated in experimental fields. In one of these experimental fields, in San Giorgio Piacentino (Italy), a heavy bug infestation was observed. The species was identified as Nysius cymoides (Spinola) (Heteroptera Lygaeidae), a polyphagous species known as a pest of different crops. It occurs in the Mediterranean area from the sea level to the alpine meadows.
\end{abstract}

\section{Introduction}

Quinoa (Chenopodium quinoa Willd.) is an Andean grain grown in South America for thousands of years. It has been a staple food for local people in Peru, Bolivia, Chile, Ecuador and Colombia, throughout history.

Nowadays, the popularity of this Andean grain is worldwide growing, as more and more people become interested in its extraordinary nutritional properties, first of all, its lack of gluten (Jacobsen, 2003; Bendevis et al., 2013). Quinoa seeds have in fact a high content of well-balanced proteins (Jancurová et al., 2009; Christiansen et al., 2010), whose quality is close to milk ideal protein (Koziol, 1992). Quinoa is a candidate crop for nutritional and agricultural diversification also in Europe (Bois et al., 2006), as well as in other world regions, where it can lead the transition to a more sustainable agricul-

Correspondence: Lidia Limonta, Department of Food, Environmental and Nutritional Sciences (DeFENS), University of Milano, via Celoria 2, 20133 Milano, Italy.

E-mail: lidia.limonta@unimi.it

Key words: Lygaeidae; quinoa; crop infestation.

Received for publication: 24 March 2016.

Revision received: 14 June 2016.

Accepted for publication: 14 June 2016.

CC Copyright S. Bocchi et al., 2016

Licensee PAGEPress, Italy

Journal of Entomological and Acarological Research 2016; $48: 5897$

doi:10.4081/jear.2016.5897

This article is distributed under the terms of the Creative Commons Attribution Noncommercial License (by-nc 4.0) which permits any noncommercial use, distribution, and reproduction in any medium, provided the original author(s) and source are credited. ture, thanks to its lower inputs requirement than conventional crops (Spehar, 2006). Interest in this culture has also been prompted by Food and Agriculture Organisation (FA0), who identified Quinoa as one of the most effective measures to improve food security (Jacobsen, 2003), and declared 2013 International Year of Quinoa (Bendevis et al., 2013; Small, 2013). Moreover, for at least 20 years the University of Copenhagen, Denmark, has been conducting studies about Quinoa adaptability to European temperate environmental conditions, selecting varieties capable of yielding up to 2.5 tha (Christiansen et al., 2010; Jacobsen et al., 2009; Jacobsen, 1997). Many other successful experiences of growing Quinoa outside its region of origin have been documented up to now: tests have been conducted in Morocco (Hirich et al., 2014), United Arabian Emirates (Rao and Shahid, 2012), Brazil (Spehar, 2006), Poland (Krzysztof, 2008), Kenya, Netherlands and United States (Jacobsen, 2003).

C. quinoa is infested by numerous insects in the Andean area, and the main pests are Eurysacca melanocampta Meyrick and E. quinoae Povolny (Lepidoptera Gelechiidae) that cause grain losses (Rasmussen et al., 2003; Costa et al., 2009). In research fields in Northern America different plant bugs, leaf miners, aphids, and noctuids caused significant injury (Robinson, 1986; Cranshaw et al., 1990; Oelke et al., 1992). Currently reports from Northern Europe include Cnephasia sp. (Lepidoptera Tortricidae), Aphis fabae L. (Homoptera Aphididae) and Lygus rugulipennis Poppius (Hemiptera Miridae), Scrobipalpa atnplicella (Röslerstamm) (Lepidoptera Gelechiidae) and Cassida nebulosa L. (Coleoptera Chrysomelidae) (Sigsgaard et al., 2008) and from Southern Europe Epitrix subcrinita Le Conte (Coleoptera Chrysomelidae), and leafhoppers (Homoptera Cicadellidae) (Rasmussen et al., 2003).

For the above-mentioned reasons, some field experiments have been carried out in North Italian conditions with the aim of assessing the possibility to optimize the agro-techniques, including strategies for Integrated Pest Management. In one of these experimental fields, during summer 2014, a bug infestation was observed on the panicles. The paper aims at describing the main results obtained in terms of identification and classification of this parasite, to be considered new for the quinoa cropping system in Italy.

\section{Materials and methods}

The quinoa field was placed in Emilia Romagna Region (North of Italy), located in the Po valley ( $45^{\circ} 60^{\prime}$ - $44^{\circ} 77^{\prime}$ lat. N; $7^{\circ} 65^{\prime}-12^{\circ} 22^{\prime}$ long. E), in the municipality of San Giorgio Piacentino. Titicaca cultivar of quinoa was sown in May using a universal drill with the density of 100 plants $\mathrm{m}^{-2}$; the control of weeds was carried out manually and crops were irrigated 3 times. The harvest was carried out by wheat harvester and the yield was about 3 tha. The crop was regularly controlled from sowing to harvest. 


\section{Results}

Bug infestation was observed during two visits to the field, at the end of June till the first week of July, close to harvest. Each panicle was infested by 1 to 5 adults identified as Nysius cimoydes (Spinola) (Hemiptera Lygaeidae) (Figure 1).

The genus Nysius Dallas 1852 belongs to the suborder Heteroptera, infra-order Pentatomomorpha, superfamily Lygaeoidea, Family Lygaeidae, Subfamily Orsillinae. It contains approximately 106 species throughout the World; about 10 live in the Euromediterranean sub-region (Péricart, 1998). Like other seed bugs, there are some species in the genus that have proven to be crop pest of wheat and other grains, as well as many vegetables. The species are generally fully winged except two closely related species found on the island of Hawaii, which are different from the rest of Nysius by exhibiting reduced nonfunctional wings, and feed on dead and dying insects (Polhemus, 1998).

The species $N$. cymoides (Figure 2) was described as Artheneis cymoides by the Italian entomologist Massimiliano Spinola: original series, collected in Genova, was probably lost. Synonyms are: Nysius albidus Dallas, 1852; Heterogaster exilis A. Costa, 1853; Nysius fuliginosus Fieber, 1861; Nysius thoracicus Horvàth, 1882.

$N$. cymoides differs from other Euro-Mediterranean species for the modest size (3.5-4 mm) and for the following characters: i) dorsal parts whitish-translucent colored; ii) general shape elongate and slender; iii) pronotum little, strongly transverse, its width is around two times the height; iv) membrane of the hemelytra hyaline and transparent, it clearly surpasses the apex of the abdomen; v) bucculae, in the lower part of the head, reduced progressively backward.

The species is present in the Holomediterranean region, extending into Macaronesian Islands, Central Europe, Middle East, Middle Asia, and Central Africa. According to Linnavuori (2007), Nysius cymoides lives in steppes, meadows, and fields. Péricart (1998) reports several wild host plants cited by various authors: Centaurea solsticialis, Artemisia absinthium, Gossypium sp., and Tamarix spp. (Lybia and Turkmenistan), bearing fruits. Schaefer and Panizzi (2001) report that it seems probable that this species is univoltine in contrast to other species of Nysius of tropical regions. This would be a useful adaptation to the Mediterranean climate of Southern Europe and adjacent areas. Rivnay (1962) observed that the nymphs were only present in the spring; adults in the field in summer did not reproduce so he concluded that this insect goes into an adult diapause in the dry summer and becomes reproductive in the spring.

\section{Discussion and conclusions}

Nysius cymoides is a polyphagous species that causes economic losses in the Mediterranean basin. In Israel, a mass infestation of $N$. cymoides occurred on cabbage and cauliflower grown for seeds, on wild mustard, and on grapevines. Sucking sap can cause losses of around $80 \%$. It was also collected on clover and alfalfa (Medicago sativa L.) fields in the summer (Rivnay 1962). The same author stated that bugs preferentially attacked cruciferous inflorescences and pods when seeds are in the milk

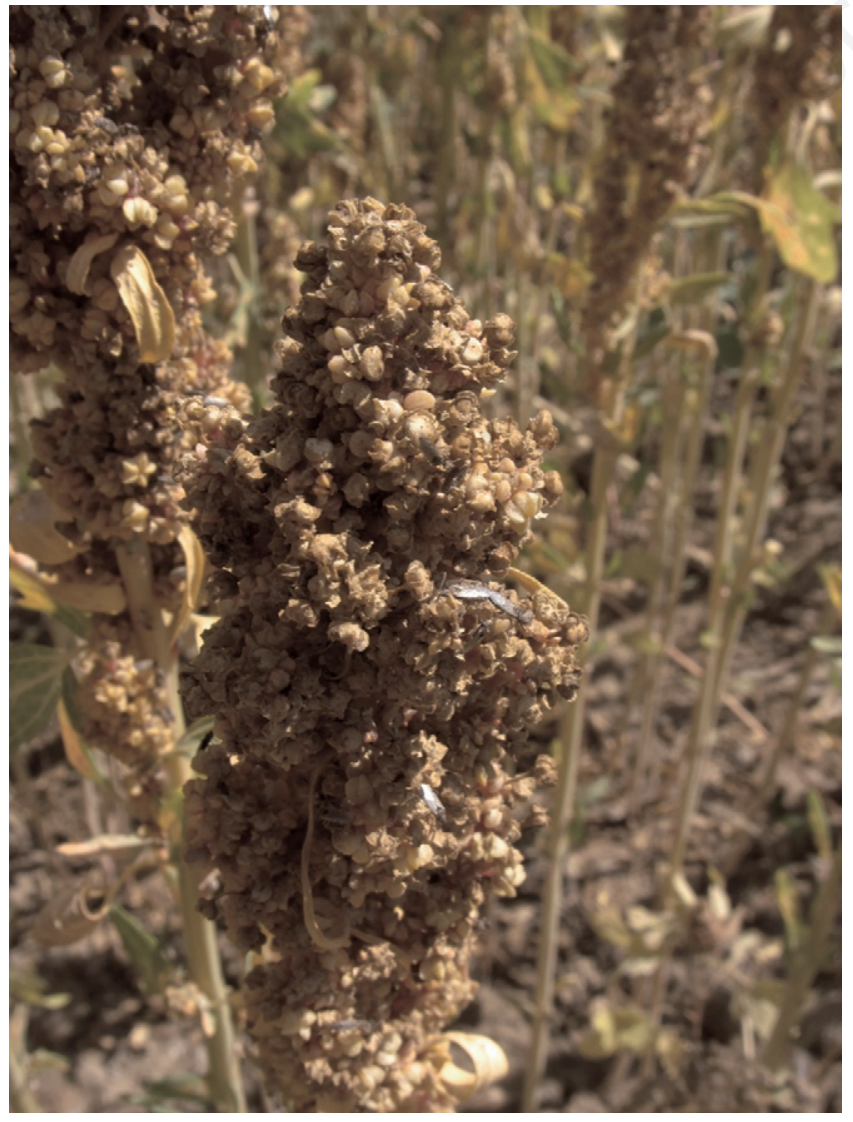

Figure 1. Nysius cymoides (Spinola) adults on quinoa panicles.

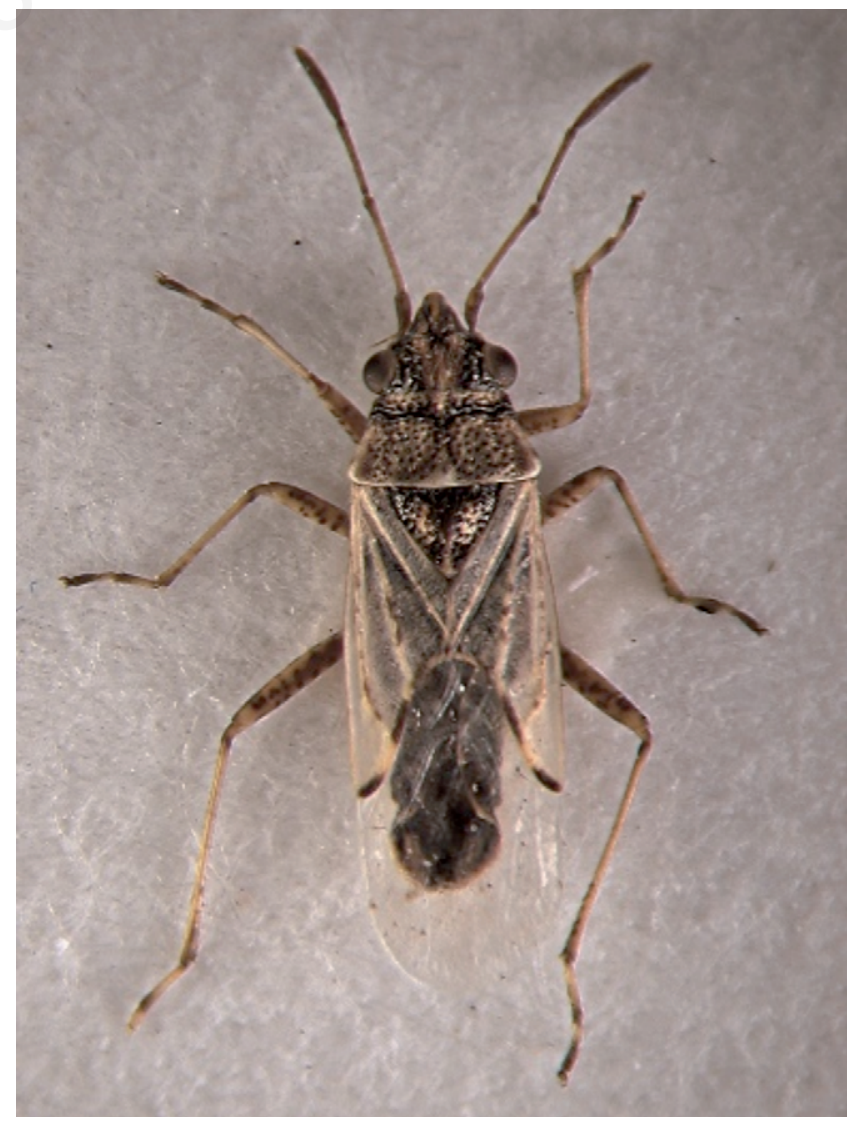

Figure 2. Nysius cymoides (Spinola). 
stage. In Negev (Gilat and Louis 1974), it attacked the introduced river red gum, Eucalyptus camaldulensis Dehnh., and the flat-topped E. occidentalis Endl. More recently, Razmjoo (2012) confirms that this species, in Iran, is present on cultivated alfalfa. Demìrel (2009) observed that adults of $N$. cymoides were recovered on four canola varieties (Brassica napus L.), cultivated in Hatay province of Turkey, as an important oil crop grown for animal feed, oil, and biodiesel. The species was recorded during the whole sampling period and its population peaked in the middle of May. The study demonstrated that $N$. cymoides was the only observed Lygaeidae species on canola plants, and its population density gradually increased and peaked during the harvest time, from late April to the beginning of May. Subsequently, Özgen (2012) quotes the first record for Mardin province (Turkey) in vineyard area. This author lists this species in Diyarbakır, Şanlıurfa and Kilis provinces where it was known in weeds. In Egypt, $N$. cymoides is part of a complex of pests of leguminous plants (Harakly and Assem, 1978). In Italy, the bug was studied by Parenzan (1985) who reported attacks to the newly introduced buxaceous plant jojoba, Simmondsia chinensis (Link.) Kellog (=Simmondsia californica Nutt.). The bug appeared to have built up large populations in the plantation on the weed Portulaca oleracea L., and then had migrated to jojoba. The damage caused by these piercing-sucking insects included wilted and necrotized tissues. Seedpods were also attacked. Some edaphic behaviors of this insect in crops are known: generally, there is a natural tendency to dioecism. Rivnay (1962) reported that the plants in a garden were totally covered with this pest. One year, millions of nymphs developed in the wild mustard fields and, when the short-lived mustard plants died back, the nymphs migrated en masse to adjoining vineyards, destroying them. Host plant quality can affect $N$. cymoides development as it was showed on different canola cultivars (Mollashai et al., 2016).

Even if this species was already recorded on Chenopodium spp., attacks to quinoa by $N$. cymoides were until now unknown. Only another species of the same genus ( $N$. raphanus Howard), reported by Cranshaw et al. (1990), destroyed stands of this plant in Colorado, USA. Since it can feed on different crops causing heavy damages, it must be monitored from milky stage to harvest to avoid economic losses.

\section{References}

BENDEVIS M.A., SUN Y., SHABALA S., ROSENQVIST E., LIU F., JACOBSEN S.E., 2013 - Differentiation of photoperiod-induced ABA and soluble sugar responses of two Quinoa (Chenopodium quinoa Willd.) Cultivars. - J. Plant Growth Regul. 33: 562-570.

BOIS J.F., WINKEL T., LHOMME J.P., RAFFAILLAC J.P., ROCHETEAU A., 2006 - Response of some Andean cultivars of quinoa (Chenopodium quinoa Willd.) to temperature: effects on germination, phenology, growth and freezing. - Eur. J. Agron. 25: 299-308.

CHRISTIANSEN J.L., JACOBSEN S.E., JøRGENSEN S.T., 2010 Photoperiodic effect on flowering and seed development in quinoa (Chenopodium quinoa Willd.). - Acta Agric. Scand. Sect. B - Soil Plant Sci. 60: 539-544.

COSTA J.F., COSIO W., CARDENAS M., YÁBAR E., GIANOLI E., 2009 Preference of Quinoa Moth: Eurysacca melanocampta Meyrick (Lepidoptera: Gelechiidae) for two varieties of quinoa (Chenopodium quinoa Willd.) in olfactometry assays. - Chil. J. Agric. Res. 69: 71-78.

CRANSHAW W.S., BORIS C.K., QIAN T. R., 1990 - Insects associated with Quinoa, Chenopodium quinoa, in Colorado. - J. Kansas Entomol. Soc. 63: 195-199.

DEMÌREL N., 2009 - Determination of Heteroptera species on canola plants in Hatay province of Turkey. - Afr. J. Agric. Res. 4: 1226-1233.

GILAT B.M., LOUIS B.M., 1974 - Biennal report 1971/1973. - Negev Research Institute for Silvicolture And Applied Ecology, Tel Aviv. 13 pp.

HARAKLY F.A., ASSEM M.A., 1978 - Ecological studies on the truly pests of leguminous plants in Egypt. Piercing and sucking pests, p. 237-
242 in: Proceedings of the 4th Conference of Pest Control, Academy of Scientific Research and Technology and National Research Centre, Cairo.

HIRICH A., CHOUKR ALLAH R., JACOBSEN S. E., EL YOUSSFI L., EL OMARI H., 2014 - El uso de riego deficitario con aguas residuales tratadas en la producción de quinua (Chenopodium quinoa Willd.) en Marruecos. Using deficit irrigation with treated wastewater in the production of quinoa (Chenopodium quinoa Willd.) in Morocco. - Revista Cientifica UD0 Agricola 12: 570-583.

JACOBSEN S.E., 1997 - Adaptation of quinoa (Chenopodium quinoa) to Northern European agriculture: studies on developmental pattern. - Euphytica 96: 41-48.

JACOBSEN S.E., 2003 - The worldwide potential for Quinoa (Chenopodium quinoa Willd.). - Food Rev. Int. 1: 167-177.

JACOBSEN S.E., JØRGENSEN I., STØLEN 0., 2009 - Cultivation of quinoa (Chenopodium quinoa) under temperate climatic conditions in Denmark. - J. Agric. Sci. 122: 47.

JANCUROVÁ M., MINAROVI OVÁ L., DANDÁR A., 2009 - Quinoa - a Review. - Czech J. Food Sci. 27: 71-79.

KOZIOL M. J., 1992 - Chemical composition and nutritional evaluation of Quinoa. - J. Food Comp. Anal. 5: 35-68.

KRZYSZTOF G., 2008 - Evaluation of the development and yielding potential of Chenopodium quinoa Willd. under the climatic conditions of Europe. - Acta Agrobot. 61: 185-189.

LINNAVUORI R. E., 2007 - Studies on the Lygaeidae s. lat. (Heteroptera) of Gilan and the adjacent provinces in northern Iran. - Acta Entomol. Mus. Nat. Pragae, 47: 57-75.

MOLLASHAHI M., SAHRAGARD A., MOHAGHEGH-NEYSHABOURI J., HOSSEINI R., SABOURI H., 2016 - Resistance of canola cultivars affect life table parameters of Nysius cymoides (Spinola) (Hemiptera: Lygaeidae). - J. Plant Prot. Res. 56: 45-53.

OELKE E.A., PUTNAM D.H., TEYNOR T.M., OPLINGER E.S., 1992 Quinoa. - Available from: https:/www.hort.purdue.edu/newcrop /afcm/quinoa.html

ÖZGEN I., 2012 - The species of suborder Heteroptera (Hemiptera) on vineyards agroecosystems which found in Diyarbakır, Elazı and Mardin provinces, Turkey. - Mun. Ent. Zool. 7: 255-258.

PARENZAN P., 1985 - Damage to jojoba (Simmondsia chinensis) from Nysius cymoides Spin. (Rhynchota, Heteroptera, Lygaeidae) in Apulia (Italy). - Entomologica 20: 99-108.

PÉRICART J., 1998 - Hémipter Lygaeidae EuroMéditerranéens, Vol. 1. Faune de France 84 A. - Paris, 469 pp.

POLHEMUS D. A., 1998 - Nysius (Heteroptera: Lygaeidae), a new species of micropterous wekiu bug from the summit of Mauna Loa volcano, Hawaii. - Proc. Entomol. Soc. Washington: 25-31.

RAO N.K., SHAHID M., 2012 - Quinoa - A promising new crop for the Arabian Peninsula. - Am. J. Agric. Environ. Sci. 12: 1350-1355.

RASMUSSEN C., LAGNAOUI A., ESBJERG P., 2003 - Advances in the knowledge of Quinoa pests. - Food Rev. Int. 19: 61-75.

RAZMJO0 M., 2012 - A faunistic survey of Hemiptera-Heteroptera found in Isfahan hay alfalfa. - J. Res. Agric. Sci. 8: 89-92.

RIVNAY E., 1962 - Field crops in the Near East W. - Junk eds., The Hague.

ROBINSON R.G., 1986 - Amaranth, quinoa, ragi, teff, and niger. Tiny seeds of ancient history and modern interest. - Minn. AES Bull. 2949: 1-23.

SCHAEFER C.W., PANIZZI A.R., 2001 - Heteroptera of economic importance. - CRC Press. pp. 219-220

SIGSGAARD L., JACOBSEN S. E., CHRISTIANSEN J. L., 2008 - Quinoa, Chenopodium quinoa, provides a new host for native herbivores in northern Europe: case studies of the moth, Scrobipalpa atriplicella, and the tortoise beetle, Cassida nebulosa. - J. Insect Sci. 8: 50-53.

SMALL E., 2013 - Blossoming treasures of biodiversity. Quinoa - is the United Nations' featured crop of 2013 bad for biodiversity? Biodiversity 14: 169-179.

SPEHAR C. R., 2006 - Adaptação da Quinoa (Chenopodium quinoa Willd.) para incrementar a diversidade agrícola e alimentar no Brasil. - Cad. Ciência Tecnol. Brasília 23: 41-62. 